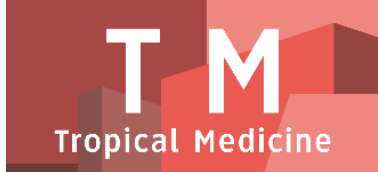

PAPER - OPEN ACCESS

\title{
Aktivitas Analgetik Ekstrak Etanol Daun Pugun Tanoh (Picria Fel-Terrae Lour) Pada Mencit (Mus Musculus)
}

\author{
Author : : Yuandani \\ DOI $\quad: 10.32734 /$ tm.v1i3.284 \\ Electronic ISSN : 2623-0542 \\ Print ISSN : 2623-0550
}

Volume 1 Issue 3 - 2018 TALENTA Conference Series: Tropical Medicine (TM)

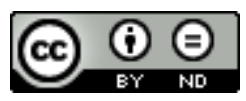

This work is licensed under a Creative Commons Attribution-NoDerivatives 4.0 International License.

Published under licence by TALENTA Publisher, Universitas Sumatera Utara
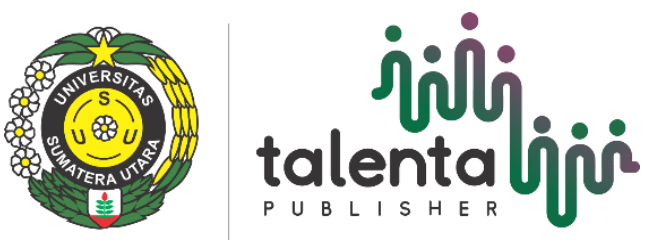


\section{inili talenta ต̊ำ TALENTA Conference Series}

Available online at https://talentaconfseries.usu.ac.id

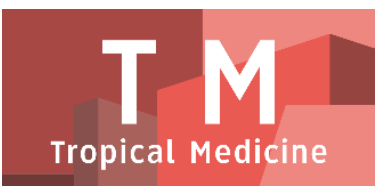

\title{
Aktivitas Analgetik Ekstrak Etanol Daun Pugun Tanoh (Picria Fel- Terrae Lour) Pada Mencit (Mus Musculus)
}

\author{
Yuandani $^{\mathrm{a}^{*}}$, Martha Yohana ${ }^{\mathrm{b}}$, Marianne $^{\mathrm{c}}$ \\ ${ }^{a b c}$ Departemen Farmakologi Farmasi, Fakultas Farmasi, Universitas Sumatera Utara, Medan 20155 \\ yuandani@usu.ac.id
}

\begin{abstract}
Abstrak
Pugun Tanoh (Picria fel-terrae Lour) telah digunakan dalam pengobatan tradisional untuk mengatasi sakit perut dan inflamasi. Kajian ilmiah perlu dilakukan untuk membuktikan khasiat pugun tanoh tersebut khususnya sebagai analgetik. Pengujian aktivitas analgetik ekstrak etanol daun $P$. fel-terrae dilakukan menggunakan metode plantar tes infrared. Analisis dilakukan dengan membandingkan waktu yang dibutuhkan hewan uji untuk menahan induksi panas dari infrared (IR) pada panjang gelombang 96 $\mathrm{nm}$, setelah pemberian ekstrak dengan dosis 25,50 dan $100 \mathrm{mg} / \mathrm{kg}$ bb. Morfin $10 \mathrm{mg} / \mathrm{kg}$ bb dan antalgin $300 \mathrm{mg} / \mathrm{kg}$ bb digunakan sebagai kontrol positif. Kelompok kontrol negatif hanya menerima CMC-Na 0,5\%. Pengamatan dilakukan selama 90 menit. Ekstrak etanol daun P. fel-terrae menunjukkan efek analgetik jika dibandingkan dengan kelompok kontrol negatif $(\mathrm{P}>0.05)$. Nilai AUC (Area Under Curve) waktu respon terhadap nyeri semakin tinggi dengan meningkatnya dosis. Ekstrak pada dosis $100 \mathrm{mg} / \mathrm{kg}$ bb menunjukkan aktivitas paling tinggi dengan efek analgetik yang lebih baik dari antalgin $300 \mathrm{mg} / \mathrm{kg} b \mathrm{~b}(\mathrm{p}<0,05)$ tetapi memiliki efek analgetik yang sama dengan morfin $10 \mathrm{mg} / \mathrm{kg} b \mathrm{~b}(\mathrm{p}>0,05)$. Ekstrak etanol daun P. fel-terrae mempunyai efek analgetik dan berpotensi untuk dikembangkan menjadi fitofarmaka.
\end{abstract}

Kata kunci: P. fel-terrae, plantar tes infrared, analgetik, AUC

\begin{abstract}
Pugun tanoh ((Picria fel-terrae Lour) has been used in traditional medicine to treat stomach ache dan inflammation. Scientific study is necessary to prove the biologic activity of pugun tanoh especially as analgesic. Analgetic activity of ethanol extract of $P$. fel-terrae leaves was evaluated using infrared plantar test method. Analysis was carried out by comparing the pain onset after induced by infrared at $96 \mathrm{~nm}$, after administrated with extract at doses of 25, 50 dan $100 \mathrm{mg} / \mathrm{kg} \mathrm{bw}$. Morfin $10 \mathrm{mg} / \mathrm{kg} \mathrm{bw}$ and antalgin $300 \mathrm{mg} / \mathrm{kg}$ bw were used as positive control. Negative control group was administered with Na-CMC 0,5\% only. Observation was performed within 90 minutes. The ethanol extract of $P$. fel-terrae leaves depicted analgesic effect hich was compared to negative control $(\mathrm{P}<0.05)$. The AUC (Area Under Curve) value of reponse time to pain was in a dose dependent manner. Off all doses, dose of $100 \mathrm{mg} / \mathrm{kg}$ bw displayed highest actvity and higher than antalgin $300 \mathrm{mg} / \mathrm{kg}$ bw $(\mathrm{P}<0.05)$ but was comparable with morfin $(\mathrm{P}>0.05)$. The ethanol extract of $P$. fel-terrae leaves showed analgesic activity and has therapeutic potential to be developed as phytopharmaca.
\end{abstract}

Keywords: P. fel-terrae, plantar test infrared, analgesic, AUC 


\section{Pendahuluan}

Analgetik adalah senyawa yang dalam dosis terapeutik meringankan atau menekan rasa nyeri, tanpa memiliki kerja anestesi umum [1]. Pada penggunaan lama atau dalam dosis tinggi analgetik non-narkotik menimbulkan efek samping seperti gangguan pencernaan, hati dan ginjal. Analgetik narkotik menimbulkan adiksi yang tidak diinginkan [2].

Oleh karena itu, diperlukan alternatif pengobatan yang memiliki efikasi yang lebih baik dengan resiko efek samping yang lebih rendah. Salah satu tumbuhan yang telah digunakan oleh masyarakat dalam pengobatan tradisional adalah pugun tanoh (Picria fel-terrae Lour).

Pugun Tanoh (Picria fel-terrae Lour) termasuk suku Scrophulariaceae yang sering digunakan oleh masyarakat Desa Tiga Lingga, Kabupaten Dairi, Provinsi Sumatera Utara untuk mengobati sesak napas, batuk rejan, kudis, memar, bengkak, cacingan, dan sakit perut [3]. Masyarakat di kota Maluku menggunakan pugun tanoh untuk mengobati kolik dan malaria [4]. Beberapa penelitian menunjukkan bahwa pugun tanoh juga mempunyai efek penyembuhan luka bakar [5] dan antidiabetes [6]. Juwita (2009) [7] melaporkan aktivitas antiinflamasi daun pugun tanoh, oleh karena itu tanaman ini juga berpotensi sebagai analgetik. Namun demikian, kajian mengenai aktivitas analgetik daun pugun tanoh belum diketahui dari penelusuran informasi yang telah dilakukan.

Daun pugun tanoh mengandung berbagai senyawa metabolit sekunder seperti yang telah dilaporkan padas penelitian sebelumnya, yaitu glikosida, flavonoid, saponin dan terpenoid [7]. Kandungan senyawa bioaktif tersebut menguatkan potensi pugun tanoh untuk dikembangkan sebagai fitofarmaka. Pada penelitian ini, dilakukan kajian aktivitas analgetik ekstrak etanol daun pugun tanoh dengan metode plantar tes infrared.

\section{Bahan dan Metode}

\subsection{Bahan dan Alat}

Bahan yang digunakan dalam penelitian ini adalah etanol (Smartlab, Indonesia) dan Na-CMC (Natrium-Carboxy Methyl Cellulose) yang dibeli dari Sigma Aldrich, USA. Alat-alat yag digunakan adalah rotary evaporator (Heidolph VV-300, Germany), timbangan hewan (Presica Geniweigher GW-1500, Swiss), timbangan digital (Vibra, Japan), dan plantar infrared.

\subsection{Sampel}

Daun pugun tanoh yang dikumpulkan dari Kecamatan Pancurbatu Kabupaten Deli Serdang. Identifikasi tumbuhan dilakukan di Herbarium Medanense (MEDA) Universitas Sumatera Utara.

\subsection{Ekstraksi}

Simplisia daun pugun tanoh kering sebanyak 6010,7 g dimaserasi dengan sejumlah pelarut etanol 96\% sampai terendam dalam wadah kaca yang dibungkus dengan alumunium foil. Selanjutnya dibiarkan selama 5 hari terlindung dari cahaya sambil sesekali diaduk. Setelah 5 hari disaring, tampung maserat pada botol gelap, dan ampas di maserasi kembali dengan etanol 96\%, dibiarkan selama 2 hari terlindung dari cahaya, disaring. Proses dilakukan sampai warna filtrat menjadi bening. Ekstrak etanol tersebut dipekatkan menggunakan alat evaporator hingga diperoleh ekstrak kental ekstrak etanol daun pugun tanoh [8].

\subsection{Pengujian Aktivitas Analgetik}

Aktivitas analgetik ekstrak etanol daun pugun tanoh dievaluasi menggunakan metode platar tes infrared seperti yang dsebutkan dalam penelitian sebelumnya [9]. Mencit percobaan 30 ekor dibagi menjadi enam kelompok yaitu kelompok I, II, III, IV, V dan VI. Masing-masing mencit ditimbang berat badan, kemudian dilakukan pengujian analgetik dengan metode plantar tes infrared.
Kelompok I
: 5 ekor mencit diberikan $\mathrm{Na}-\mathrm{CMC}$ dosis $0,5 \% / \mathrm{bb}$.
Kelompok II
: 5 ekor mencit diberikan EEDPT dosis $25 \mathrm{mg} / \mathrm{kg}$ bb.
Kelompok III
: 5 ekor mencit diberikan EEDPT dosis $50 \mathrm{mg} / \mathrm{kg}$ bb. 
Kelompok IV $\quad: 5$ ekor mencit diberikan EEDPT dosis $100 \mathrm{mg} / \mathrm{kg}$ bb.

Kelompok V

Kelompok VI
: 5 ekor mencit diberikan morfin dosis $10 \mathrm{mg} / \mathrm{kg}$ bb.

: 5 ekor mencit diberikan antalgin dosis $300 \mathrm{mg} / \mathrm{kg}$ bb.

Obat disuspensikan dan diberikan secara oral. Hewan diletakkan kedalam kotak, didiamkan selama 15 menit sampai mencit tenang, kemudian diarahkan panas infrared (IR) $96 \mathrm{~nm}$ tepat ketelapak kaki hewan. Diamati dan dicatat, berapa lama waktu yang dibutuhkan mencit sampai mengakat telapak kakinya. Kemudian perlakuan diarahkan lagi sinar infrared ketelapak kaki mencit, dilakukan selang waktu 10 menit sampai 90 menit. Nilai AUC dihitung mengunakan rumus di bawah ini [10].

Keterangan:

$$
[A U C]_{t_{n-1}}^{t_{n}}=\frac{R N_{n-1}+R N_{n}}{2}\left(t_{n}-t_{n-1}\right)
$$

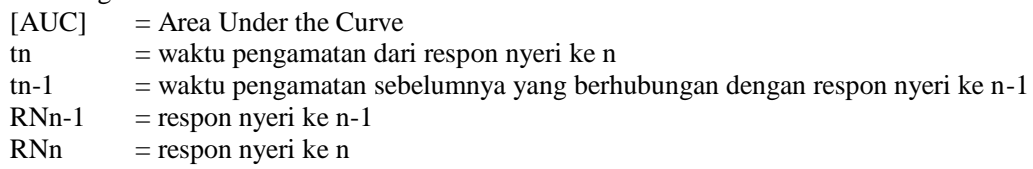

\subsection{Analisis Data}

Data hasil penelitian dianalisis menggunakan program Statistical Product and Service Solution (SPSS) versi 17 yaitu menggunakan metode one way analisis of variance (ANOVA) dengan tingkat kepercayaan 95\% dilanjutkan dengan uji post hoc tukeyuntuk mengetahui kelompok mana yang mempunyai pengaruh sama atau berbeda secara signifikan dengan obat pembanding.

\section{Hasil Dan Pembahasan}

Pengujian aktivitas analgetik dilakukan dengan menggunakan metode plantar tes infrared (IR). Respon nyeri setelah diinduksi panas infrared pada mencit ditunjukkan dalam bentuk menjilat kaki. Analisis dilakukan dengan cara membandingkan waktu yang dibutuhkan hewan uji untuk menahan induksi panas dari infrared (IR) $96 \mathrm{~nm}$, setelah pemberian ekstrak etanol daun pugun tanoh, morfin, antalgin dan CMC-Na 0,5\%. Pengamatan dilakukan selama 90 menit. Waktu rata-rata respon mencit menahan induksi panas infrared (IR) tiap 10 menit selama 90 menit ditunjukkan pada Tabel 2. Ekstrak etanol daun P. fel-terrae dosis $50 \mathrm{mg} / \mathrm{kg}$ bb menunjukkan waktu respon menahan induksi panas yang relatif singkat dan tidak berbeda dengan kontrol negatif. Hal ini menujukkan ekstrak etanol daun P. fel-terrae mempunyai aktivitas analgetik pada dosis 50 dan $100 \mathrm{mg} / \mathrm{kg}$ bb.

Tabel 2. Hasil waktu rata-rata respon mencit menahan induksi panas infrared (IR) tiap 10 menit selama 90 menit

\begin{tabular}{|c|c|c|c|c|c|c|c|c|c|}
\hline \multirow{2}{*}{ Kelompok } & \multicolumn{9}{|c|}{ Waktu perlakuan menit ke- } \\
\hline & 10 & 20 & 30 & 40 & 50 & 60 & 70 & 80 & 90 \\
\hline & \multicolumn{9}{|c|}{ Rata-rata respon nyeri (detik) } \\
\hline CMC-Na $0,5 \%$ & 3,9 & 3,7 & 4,8 & 4,1 & 5,2 & 3,5 & 4,1 & 5,6 & 5,9 \\
\hline $\begin{array}{l}\text { EEDPT } 25 \mathrm{mg} / \mathrm{kg} \\
\mathrm{bb}\end{array}$ & 8,4 & 6,7 & 7,8 & 9,6 & 7,8 & 8,5 & 9,5 & 8,2 & 6,5 \\
\hline $\begin{array}{l}\text { EEDPT } 50 \mathrm{mg} / \mathrm{kg} \\
\mathrm{bb}\end{array}$ & 13,6 & 10,3 & 10,5 & 11,7 & 11,7 & 12,9 & 12,6 & 13,9 & 13,9 \\
\hline $\begin{array}{l}\text { EEDPT } 100 \mathrm{mg} / \mathrm{kg} \\
\mathrm{bb}\end{array}$ & 19,3 & 19,5 & 16,1 & 12,4 & 16,6 & 17,0 & 14,4 & 20,2 & 10,1 \\
\hline $\begin{array}{l}\text { Morfin } 10 \mathrm{mg} / \mathrm{kg} \\
\text { bb }\end{array}$ & 17,2 & 19,1 & 19,8 & 19,2 & 11,7 & 15,0 & 15,0 & 15,7 & 15 \\
\hline Antalgin & 14,9 & 12,6 & 9,6 & 13,4 & 14,6 & 14,4 & 12,9 & 9,9 & 12,2 \\
\hline
\end{tabular}


$300 \mathrm{mg} / \mathrm{kg}$

EEDPT: Ekstrak etanol daun pugun tanoh

Hasil perhitungan nilai luas area di bawah kurva (Area Under the Curve atau AUC) respon nyeri menunjukkan bahwa ekstrak pada dosis $25 \mathrm{mg} / \mathrm{kg}$ bb mempunyai AUC respon nyeri yang paling kecil dibandingkan dengan kelompok perlakuan lainnya (Gambar 1). AUC respon nyeri ekstrak dosis $100 \mathrm{mg} / \mathrm{kg}$ bb lebih tinggi dari AUC respon nyeri antalgin $300 \mathrm{mg} / \mathrm{kg}$ bb $(\mathrm{P}<0.05)$ dan tidak jauh berbeda dengan AUC respon nyeri morfin $10 \mathrm{mg} / \mathrm{kg} b b(\mathrm{P}>0.05)$. Semakin besar nilai AUC yang diperoleh maka efek analgetik yang dihasilkan semakin baik. Berdasarkan hasil skrining fitokimia penelitian sebelumnya dikethaui daun pugun tanoh mengandung flavonoid [7]. Flavonoid berperan sebagai analgetik yang mekanisme kerjanya menghambat kerja enzim siklooksigenase untuk menghasilkan prostaglandin. Prostaglandin merupakan hormon lokal yang disintesis di berbagai organ dan bekerja di tempat itu juga. Prostaglandin dilepaskan ke peredaran darah dengan cepat saat terjadi kerusakan jaringan. Prostaglandin terlibat pada terjadinya nyeri yang berlangsung lama, proses peradangan dan timbulnya demam [1] Rasa nyeri akan berkurang dengan terhambatnya produksi prostaglandin oleh asam arakidonat [11].

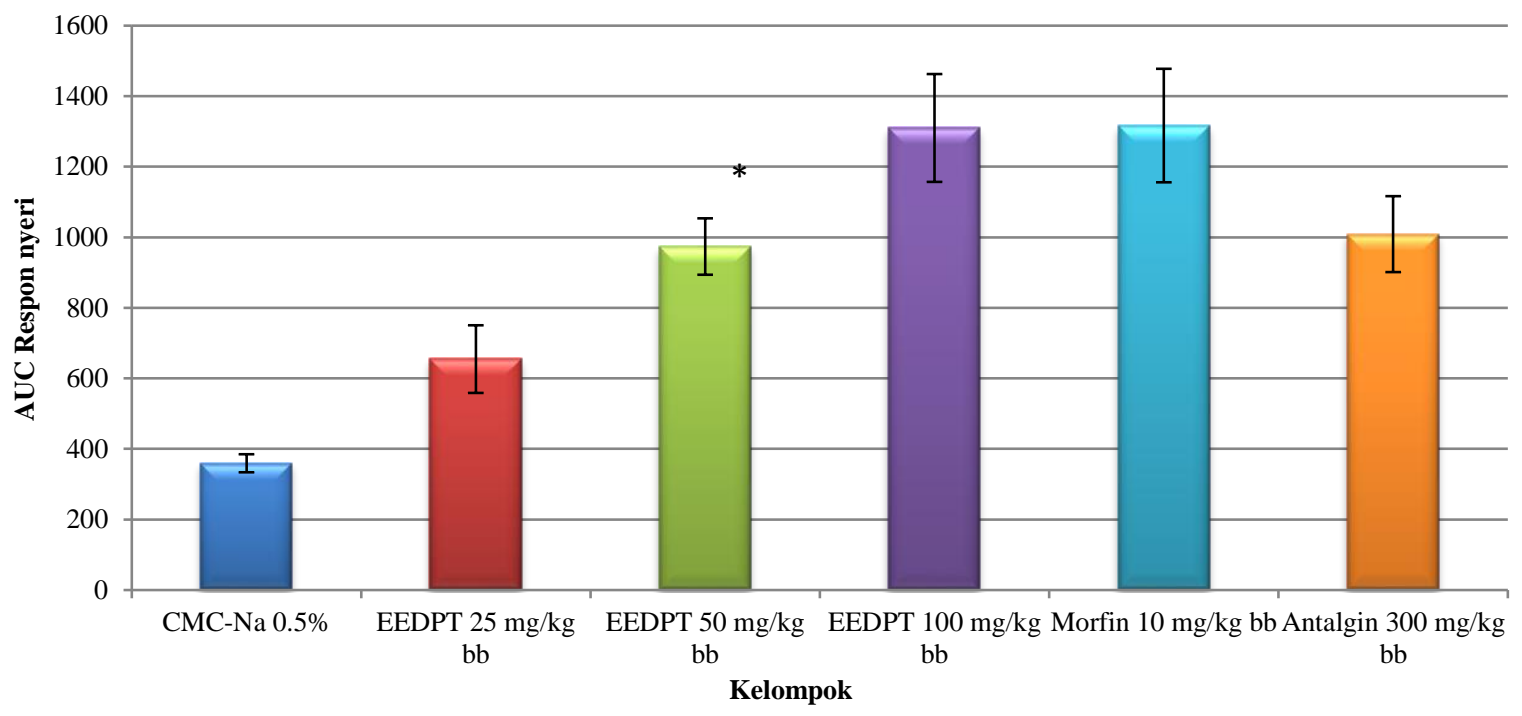

Gambar 1. Rerata AUC respon nyeri mencit setelah di induksi infrared dan diberi perlakuan ekstrak etanol daun pugun tanoh $(\mathrm{EEDPT}) ; * \mathrm{P}<0,05$ signifikan dengan negatif kontrol

\section{Kesimpulan}

Ekstrak etanol daun pugun tanoh (P. fel-terrae) mampu meningkatkan waktu rata-rata respon mencit menahan induksi panas infrared, mengindikasikan adanya efek analgetik ekstrak khususnya pada dosis 50 dan $100 \mathrm{mg} / \mathrm{kg} \mathrm{bb}$. Hasil ini didukung oleh nilai AUC respon nyeri setelah pemberian ekstrak yang lebih tinggi dibanding kontrol negatif. Ekstak dosis $100 \mathrm{mg} / \mathrm{kg}$ bb menunjukkan efek analgetik yang lebih tinggi dibandingkan antalgin dan sebanding dengan morfin.

\section{Ucapan Terima Kasih}

Penelitian ini didukung oleh Universitas Sumatera Utara yang telah menyediakan fasilitas.

\section{Daftar Pustaka}

[1] Mutschler, E, 1991. Dinamika Obat: Buku Ajar Farmakologi dan Toksikologi.Ed. 5. Penerjemah: Widianto, M. dan A.S. Kanti. Bandung, ITB, p:177-178. 
[2] Tjay, T.H., dan Rahardja, K, 2002. Obat-Obat Penting:Khasiat, Penggunaan dan Efek-Efek Sampingnya. Ed. 5. Elex Media Komputindo Kelompok Gramedia, Jakarta, p:312; 315; 349-350.

[3] Agromedia, 2008. Buku Pintar Tanaman Obat. Disunting Oleh: Agung danTinton. Cetakan I. Agromedia Pustaka, Jakarta, p: $64-65$.

[4] Proseanet, 2009. Picria fel-terrae Lour.Tanggal akses 21 maret 2014. http://www.proseanet.org/prohati2/browser.php?docsid=459.

[5] Shubhiya, R.F, 2013. Efek Penyembuhan Luka Bakar Dari Sediaan Gel Ekstrak Etanol Daun Pugun Tanoh (Curanga fel-terrae (Lour.) Merr.). Skripsi. Medan: Fakultas Farmasi Universitas Sumatera Utara.

[6] Sitorus, P, 2012. Isolasi dan Karakterisasi Senyawa Steroid/Triterpenoid dari Ekstrak $n$-heksana Daun Poguntano (Picria fel-terrae) yang Berkhasiat Sebagai Antidiabetes. Abstrak. Medan: Fakultas Farmasi Universitas Sumatera Utara.

[7] Juwita, N.A, 2009. Karakterisasi Simplisia dan Uji Efek Antiinflamasi Ekstrak Etanol Daun Pugun Tanoh (Curanga fel-terrae Merr.) Terhadap Mencit Jantan. Skripsi. Medan: Fakultas Farmasi Universitas Sumatera Utara.

[8] Ditjen POM, 1995. Materia Medika Indonesia. Jilid VI. Departemen Kesehatan RI. Jakarta, p: 297-326, 300-304, 306, 333-340.

[9] Marjoni, M.R., Zulfisa, and Renti, 2017. The Analgesic Effect of Aqueous Extract of Sisik Naga Leaves (Pyrrosia piloselloides (L.)M.G. Price) on White Female Mice (Mus musculus). Journal of Pharmacology and Toxicological Studies. 5(2):6.

[10] Prayoda, S. (2008). Efek Antiinflamsi Ekstrak Etanol Daun Kumis Kucing (Orthosiphon stamineus Benth.)

Pada Tikus Putih Jantan Galur Wistar. Skripsi. Surakarta: Fakultas Farmasi Universitas Muhammadiyah Surakarta.

[11] Gunawan, S.G., Setiabudy, R., Nafrialdi, Elsyabeth, editor. (2008). Farmakologi dan Terapi.Ed. 5. FK UI,

Jakarta, p:77. 